I 000 develops megaloblastic anaemia. Often the cause does not seem to be due to direct dietary deficiency of folic acid. A survey of some 855 cases of macrocytic anaemia seen in our clinic in Edinburgh during the period 1940-54 indicates four points of special interest. Firstly, it does not follow that because a patient has a macrocytic anaemia, as judged by a high colour index and a high mean cell volume, he necessarily has a megaloblastic anaemia. Secondly, it is apparent that in Edinburgh if a patient has a macrocytic anaemia it is six chances to one that he has a megaloblastic anaemia. Thirdly, if he has a megaloblastic anaemia it is nearly six chances to one that he is suffering from Addisonian pernicious anaemia. Fourthly, excluding Addisonian pernicious anaemia, the only two forms of megaloblastic anaemia of numerical importance are those due to malabsorption and to pregnancy and the puerperium, unlike the megaloblastic anaemias in Africa and in the Far East, which are frequently due to direct nutritional deficiency.

There are few physicians in Great Britain, in active practice in hospitals at the present time, who can say, like myself, that they were in charge of patients suffering from Addisonian pernicious anaemia for a period of 6 years before liver therapy was discovered. It is only those who personally watched the invariably tragic and fatal course of this disease who can appreciate the amazing results produced to-day by the injection of a few micrograms of cyanocobalamin. It is no exaggeration to say that the research work undertaken during the last 25 years, which has led to the unravelling of so many mysteries of the megaloblastic anaemias and which has produced such potent remedies as cyanocobalamin and folic acid, constitutes one of the greatest triumphs of science over disease.

It is my pleasure to declare the one-hundredth meeting of The Nutrition Society open.

\title{
Diet and anaemia: zymotic and other factors
}

\section{By B. S. Platt, Human Nutrition Research Unit, Medical Research Council Labor- atories, Holly Hill, London, N.W.3 and G. R. WADsworth, London School of Hygiene and Tropical Medicine}

By anaemia we mean a reduction in the amount of total circulating haemoglobin (Wintrobe, 1954); this definition is preferred to that which defines anaemia in terms of a lowered concentration of haemoglobin in the blood which may be unimpressive owing to changes in plasma volume (Allington \& Taylor, I955; Hope \& Verel, 1955). The main part of this paper will be concerned with the role of protein in maintaining normal amounts of haemoglobin in the blood.

In the space available it is not possible to discuss such aspects as the interrelationship of protein and hormone synthesis, the new work on a humoral factor in the regulation of haematopoiesis (Van Dyke, Contopoulos, Williams, Simpson, Lawrence \& Evans, 1954), and the similarity of the characteristics of some tropical anaemias variously attributed to infections and infestations and protein malnutrition (Trowell, 
Davies \& Dean, I954a,b; Woodruff, I955). The discussion will therefore be confined to the effects of infections, infestations, trauma and neoplasia on protein metabolism and therefore on haematopoiesis. We were, however, invited to discuss factors in food which interfere with blood formation; this subject will be briefly reviewed first.

\section{Chemicals in food causing anaemia}

The effects of lead on the blood have been known for a long time (Aub, Fairhall, Minot \& Reznikoff, 1925), and contamination of food and beverages, especially beer, can still occur. Selenium also can cause anaemia (McCollum, Orent-Keiles \& Day, 1939); the metal is taken up from seleniferous soils or insecticides into plant proteins and may thus appear, for example, in wheat flour. There has been in recent years an increasing use of a wide variety of chemicals in food production and processing (Platt, 1955). The presence of some of these chemicals is 'intentional', for example as food additives, that of others is 'unintentional', for example as residues left after crop spraying or treatment during storage. Many of these substances are powerful poisons and some of them are known to produce anaemia in experimental animals. Experience with a number of drugs--chloramphenicol (Hargraves, Mills \& Heck, 1952; Smiley, Cartwright \& Wintrobe, 1952), primaquine and other drugs (Beutler, Dern, Flanagan \& Alving, I955), primidone (Girdwood \& Lenman, 1956), --illustrates the potential risk of producing anaemia from the ingestion of chemicals.

Naturally occurring substances which may contribute to the development of anaemia

Substances in the flower of the bean, Vicia fava, can bring about erythrocyte agglutination and haemolysis, and produce the condition known as favism. It is suspected that other known conditions, for example 'Baghdad spring fever', may be of similar origin, and the presence of haemagglutinins in plant material (Morgan $\&$ Watkins, 1953) may be important in this connexion.

Fibre in foods, especially in whole-grain meals, may interfere with digestion and absorption (Cowgill \& Anderson, 1932) and thus affect the availability of materials necessary for haematopoiesis. Phytic acid, and phosphates liberated by hydrolysis of phytic acid or from dietary sources, are known to interfere with iron absorption (McCance, Edgecombe \& Widdowson, I943; Tøtterman, 1949). The importance of these factors in the development of iron-deficiency anaemia is, however, not known; although Pett (1952, 1954) found an increased incidence of iron-deficiency anaemia in children when they were given in their diet flour containing bone meal. Wheat gluten plays an important part in causing coeliac disease and idiopathic steatorrhoea (Dicke, I950; van de Kamer, Weijers \& Dicke, r953) and anaemia is a feature of both these diseases. This is attributed to the effect of gluten on the assimilation of iron, vitamin $\mathrm{B}_{12}$ and folic acid (Brøchner-Mortensen, 1943; Robineaux, 1952; Girdwood, 1953). Anaemia due to folic-acid deficiency is also a feature of the sprue syndrome, and although a dietary factor has not been clearly demonstrated in tropical sprue an association with unsaturated seed fats in the diet has been suggested (Frazer, 1952). 
Improvement in tropical sprue may sometimes follow treatment with sulphonamides and antibiotics (Rogers, 1938; Frazer, I952), and intensive treatment with antibiotics may give rise to a sprue-like diarrhoea (Manson-Bahr, I953). Foy, Kondi \& Manson-Bahr (1955) found that administration of penicillin by mouth to patients with megaloblastic anaemia resulted in a rise in serum vitamin $B_{12}$ levels. Thus there is evidence of an association between anaemia and intestinal bacteria. The gut flora is known to be profoundly affected by the nature of the diet (Johansson \& Sarles, 1949) but little is known of the relationship between such changes and haematopoiesis, although the results of investigations by Davidson (1928) and Girdwood (1950-3) may be significant.

\section{Intestinal parasites}

Intestinal parasites are often introduced with food, and for that reason come up for consideration in this review. They may compete with the body for nutrientsWinfield (1937) has drawn attention to the enormous use of food by the round-worm -as well as interfering with normal assimilation. The fish tapeworm can absorb large quantities of vitamin $B_{12}$ (von Bornsdorff \& Gordin, 1952), but some doubt of the importance of this in causing deficiency exists (Karparenen \& Tøtterman, 1954).

\section{Protein and haematopoiesis}

Pauling (1955) points out that haemoglobin, as a protein, is unique among the hundred thousand other proteins that are to be found in the human body, one reason being that it is present in an unusually large amount ( $1 \%$ of the body-weight). The life span of the red blood cell is about 120 days (Callender, Powell \& Witts, 1945); since there are 26 million million erythrocytes in the blood of the normal adult male, the number destroyed and replaced each day is $2 \cdot 16 \times 10^{11}$. This represents a turnover of about $6 \mathrm{~g}$ haemoglobin so that the amount of globin returned to the protein pool is about one-tenth the estimated total daily protein requirement (Wintrobe, 1954).

In addition to the protein of haemoglobin, protein is also present in the intracellular enzymes, the red-cell stroma, and in other enzyme systems which are an integral part of the haematopoietic system (Tishkoff, Robscheit-Robbins \& Whipple, 1953; Prankerd, 1955). Shortage of protein might, therefore, be expected to be an important factor in causing subnormal red-cell production, and should be given more consideration as a cause of anaemia. Protein shortage is more likely to occur after haemorrhage; in haemolysis, when the products of red-cell destruction are not returned to the metabolic pool; in the physiological conditions of growth, pregnancy and lactation; and in the course of infections, infestations, cancer and tissue destruction. It is useful in considering the place of protein in haematopoiesis to have in mind the conception of the 'erythron' (Boycott, 1929-30). 
It has been said that haemoglobin formation takes precedence over the formation of other proteins, including plasma proteins (Whipple, 1942), and that body protein stores must be greatly depleted and the intake of protein grossly deficient over a long time before reduction in haemoglobin formation occurs (Whitby \& Britton, I953). One aspect of this question which does not seem to have been considered is that manifestations of protein deficiency may be more evident in some tissues and plasma than in haemoglobin because of the relatively large bulk of the latter. It is true that proteins of the erythrocyte may differ in behaviour from that of proteins of some other body cells. For example, it is now established that once protein is laid down in haemoglobin it remains there until the cell disintegrates (Muir, Neuberger \& Perrone, 1952). This protein is therefore immobilized from the protein pool; nevertheless, such is the rate of breakdown of erythrocytes that $6 \mathrm{~g}$ haemoglobin is required each day for the formation of new cells, and this quantity, as stated above, represents a considerable proportion of the total body requirement for protein. The protein released from erythrocyte breakdown cannot be regarded as specially available for haematopoiesis (Yuile, 1949). It is returned to the common protein pool from which all tissues, including the erythron, must draw in competition for the formation of new cellular material. If the conclusions of Whipple and his colleagues (Tishkoff, Yuile, Robscheit-Robbins \& Whipple, I955) are correct haemoglobin may be synthesized from stroma protein and the latter from material present in the plasma, that is from material presumably available to all other tissues.

Robscheit-Robbins \& Whipple (1955) showed that the length of time necessary for dogs to recover from anaemia caused by repeated haemorrhage in association with a low-protein diet, i.e. for 'doubly-depleted' animals, was much greater than that for recovery from phenylhydrazine anaemia, thus demonstrating that shortage of protein does influence erythropoiesis. They also showed that doubly-depleted dogs were still able to regenerate considerable amounts of haemoglobin, and it was concluded that this ability provided evidence of the priority of protein for haematopoiesis. Hallgren (1953) obtained similar results in doubly-depleted rats; but he emphasized that haematopoietic activity is different during recovery from dietary protein deficiency if the animals have also been bled. Further experiments of Hallgren give good grounds for doubting Whipple's views about the priority of protein for normal blood formation. These views seem to have been generally accepted and to have been responsible for the neglect of considering protein deficiency as an important cause of anaemia. Hallgren (1953) investigated the effect on animals of a lowprotein diet compared with the effect of a diet containing $22 \%$ egg albumen. From the point of view of this discussion two important observations were made: (a) the animals on a low-protein diet developed a microcytic, normochromic anaemia, which, however, judged by the haemoglobin concentration, only $10 \%$ lower than that of animals on an adequate protein intake, was slight; (b) the fall in total haemoglobin, which fell as much as $24 \%$ below that of the controls, was much more marked. The decrease in total haemoglobin was much more than the decrease in carcass protein, in agreement with the results of Metcoff, Favour \& Stare (1945). Hallgren obtained his results in growing animals in which competition for protein would be maximal 
because of the synthesis of body tissues apart from erythrocytes. In young animals on a low-protein diet, however, there were no signs of protein deficiency in the liver - no accumulation of fat as judged macroscopically and no reduction in liver protein concentration-yet in spite of this there was deficient formation of red blood cells. In fully grown animals when there was evidence of protein deficiency in the liver, there was also a reduction of total haemoglobin. In pregnant and lactating rats dietary protein shortage resulted in hardly any formation of new haemoglobin. These animals lost as much as $30 \%$ of their carcass protein, but the maximum reduction in total haemoglobin was as much as $55-60 \%$. This great fall in total haemoglobin was accompanied by only a moderate decrease in haemoglobin concentration. Depletion of iron stores did not increase anaemia due to protein depletion and a surplus of iron did not counteract this anaemia.

It seems, therefore, that although there may be priority for available protein in the formation of erythrocytes during recovery from haemorrhage this is a period of abnormal erythropoietic activity; no evidence of any special claim for protein in erythropoiesis under more stable conditions is available.

Zymotic and similar factors and protein economy of the body. It is an old observation dating back to 1842 (Cartwright \& Wintrobe, I952) that the protein content of blood is affected in infection. In his Harvey lecture on fever, MacCallum (I9I0) drew attention to the observation that the equivalent of $2 \frac{1}{2} \mathrm{~kg}$ of muscle might be lost in 8 days and of $3.2 \mathrm{~kg}$ in 12 days in the course of infection. Grossman, Sappington, Burrows, Lavretes \& Peters (I945) found that protein losses in meningitis were large and prolonged, varying from 3 to $\mathrm{r} 80 \mathrm{~g}$; the latter loss, which is equivalent to $4.5 \mathrm{~kg}$ of muscle was accompanied by a loss of $7.5 \mathrm{~kg}$ in body-weight. It is to be noted that these losses of nitrogen may continue during convalescence.

From the work of Cuthbertson (1954) and others the so-called 'catabolic phase' of response to injury is now well recognized, though not understood. Nitrogen loss in the urine is abnormally high, unpredictable in duration and self-limiting. This response to injury is less well marked or absent in poorly nourished subjects (Browne, Hoffman, Schenker, Venning \& Weil, 1945).

There appears to be very little work on nitrogen loss in relation to anaemia. In an investigation of the effects of protein feeding on patients with chronic illness Waife, Wohl \& Reinold (I950) found that when there was a nitrogen retention of $7 \cdot 2 \mathrm{~g}$ a day--indicating an initial marked nitrogen depletion-there was a corresponding increase of only $0.6 \mathrm{~g}$ haemoglobin/100 ml.; whereas in another group less depleted and retaining $4.3 \mathrm{~g}$ nitrogen a day the increase in haemoglobin was $2.2 \mathrm{~g} / 100 \mathrm{ml}$.

Yuile, Lucas, Jones, Chapin \& Whipple (I953) using ${ }^{14} \mathrm{C}$-labelled plasma protein found $4 \%$ of the injected radioactivity in the total red-cell mass of normal dogs after 7 days. In dogs which had a sterile, turpentine abscess incorporation of radioactivity into red cells was markedly reduced, values of $0.15,0.9$ and $0.4 \%$ being found in three animals. A reduction in the uptake of radioactive material was also found in skeletal and smooth muscle, skin and hair. These investigators concluded that there was conservation and shifting of protein from less active tissues to those of more active organs such as the liver and kidney, in the absence of nitrogen intake and under 
the stress of sterile inflammation. The plasma-protein concentrations and overall nitrogen balance did not reflect the magnitude of these internal shifts.

The current explanation of the anaemia of infection. There are many ways in which infection could affect the supply of protein for haematopoiesis. There is the socalled toxic destruction of protein, and loss of appetite might be an important element. Some infesting organisms may remove protein from the gut, protein may be lost by haemorrhage as in hookworm infestation, and there may be haemolysis as in malaria.

Cartwright \& Wintrobe (1952) regard the anaemia of infection as one which develops without evidence of blood loss or clinical evidence of haemolysis. They believe that much of this anaemia is accompanied by a disturbance of iron metabolism. Wintrobe (1956) found that infection caused a slight reduction of the erythrocyte life span, and that the bone marrow, although capable in the uninfected animal of a remarkable increase in activity, was unable to compensate for this reduction by increased haematopoiesis. The explanation of this inability to maintain the normal haemoglobin content of the body in infection is not known. May it be found in a reduction of the amount of protein available for red cell formation? Many of the anaemias of infection are cured by administration of iron, but a feature of the response is the improvement in appetite. Guest (1950) has commented that the increase in appetite is so consistent with iron therapy in children, that it is undoubtedly a factor in their general improvement. Josephs (I953) has made a similar observation; neither author entertains the possibility that an increased protein intake may contribute to recovery.

Anaemia and new growths. Experiments dealing with the incorporation of alanine into normal liver and into hepatoma tissue (Frantz \& Zamecnik, I950) showed that the uptake curve for both was similar, but the rate of incorporation was about four times as great in the hepatoma as in normal liver, and recent work on nitrogen metabolism in cancer shows that much protein is diverted to non-physiological purposes, even to the extent of gross depletion of the host's tissues, and this can occur in the presence of a positive nitrogen balance (Gellhorn \& Holland, I954). It is remarkable that in the consideration of the association of anaemia with cancer (Gellhorn \& Holland, r954) the possibility of protein deficiency as a cause has not been entertained.

Anaemia and injury. The gross losses of nitrogen that occur in injury, for example in burns, and the fact that anaemia also occurs in these conditions suggests an association between injury and anaemia in regard to protein metabolism. 'This possibility was put forward by Janet Vaughan (1948), although she was evidently thinking of a deficiency of an essential amino-acid. It is worth noting that probably what really matters-with certain exceptions-when an amino-acid is relatively deficient, is its effect on the level of protein anabolism.

\section{Conclusion}

There is much evidence that an adequate supply of protein is necessary for normal haematopoiesis, but the idea that there is a prior claim for protein in the 
formation of new red cells has tended to draw attention away from protein deficiency as an important cause of anaemia. The anaemia that is associated with infection, trauma and neoplasia might well be a manifestation of a diminished supply of protein available for haematopoiesis.

The role of zymotic disease-of cancer and injury-in the development of anaemia, especially in children, in pregnant, and lactating women and in subjects with some degree of protein malnutrition, is likely to be a most fertile field for further research, which is badly needed.

\section{REFERENCES}

Allington, M. J. \& Taylor, W. H. (1955). Brit. F. Haematol. r, 241.

Aub, J. C., Fairhall, L. T., Minot, A. S. \& Reznikoff, P. (1925). Medicine, 4, I.

Beutler, E., Dern, R. J., Flanagan, C. L. \& Alving, A. S. (1955). F. Lab. clin. Med. 45, 286.

Boycott, A. E. (1929-30). Proc. R. Soc. Med. 23, 15.

Brøchner-Mortensen, K. (1943). Acta med. scand. 113, 362.

Browne, J. S. L., Hoffman, M. M., Schenker, V., Venning, V. H. \& Weil, P. (1945). Conference on Metabolic Aspects of Convalescence Including Bone and Wound Healing. Transactions of the Ninth Meeting, p. I 5. New York: Josiah Macy Jr. Foundation.

Callender, S. T., Powell, E. O. \& Witts, L. J. (1945). F. Path. Bact. 57, 129.

Cartwright, G. E. \& Wintrobe, M. M. (1952). Advanc. intern. Med. 5, 165.

Cowgill, G. R. \& Anderson, W. E. (1932). F. Amer. med. Ass. 98, 1866.

Cuthbertson, D. P. (1954). Brit. med. Bull. ro, 33.

Davidson, L. S. P. (I928). F. Path. Bact. 31, 557.

Dicke, W. K. (1950). Congr. Ass. int. Pediat. vi. Zurich, p. I 7.

Foy, H., Kondi, A. \& Manson-Bahr, P. E. C. (I955). Lancet, 269, 693-

Frantz, I. D. \& Zamecnik, P. C. (I950). In Robert Gould Research Foundation Symposia on Nutrition. Vol. 2, p. 94. Springfield, Ill.: C. C. Thomas.

Frazer, A. C. (1952). Trans. R. Soc. trop. Med. Hyg. 46, 576.

Gellhorn, A. \& Holland, J. F. (1954). Annu. Rev. Med. 5, 183.

Girdwood, R. H. (1950-3). Edin. Post-Grad. Lect. Med. 6, 193.

Girdwood, R. H. (1953). Lancet, 263, 53 .

Girdwood, R. H. \& Lenman, J. A. R. (1956). Brit. med. F. i, I46.

Grossman, C. M., Sappington, T. S., Burrows, B. A., Lavretes, P. H. \& Peters, J. P. (1945). F. clin. Invest. 24, 523 .

Guest, G. M. (1950). In Robert Gould Research Foundation Symposia on Nutrition. Vol. I, p. I44. Springfield, Ill.: C. C. Thomas.

Hallgren, B. (1953). Acta Soc. Med. upsalien. 59, 79.

Hargraves, M. M., Mills, S. D. \& Heck, F. J. (1952). J. Amer. med. Ass. I49, 1293.

Hope, A. \& Verel, O. (1955). Clin. Sci. 14, 501 .

Johansson, K. R. \& Sarles, W. B. (r949). Bact. Rev. 13, 25.

Josephs, H. W. (1953). Medicine, Baltimore, 32, 125.

Karparenen, W. J. \& Tøtterman, G. (1954). Scand. F. clin. Lab. Invest. 6, 33.

Manson-Bahr, P. H. (1953). Lancet, 265, 1955.

MacCallum, W. G. (1910). Harvey Lect. $4,27$.

McCance, R. A., Edgecombe, C. N. \& Widdowson, E. M. (1943). Lancet, 245, I26.

McCollum, E. V., Orent-Keiles, E. \& Day, H. G. (1939). The Newer Knowledge of Nutrition. 5 th ed. New York: The Macmillan Company.

Metcoff, J., Favour, C. B. \& Stare, J. J. (1945). F. clin. Invest. 24, 82.

Morgan, W. T. J. \& Watkins, W. M. (I953). Brit. F. exp. Path. 34, 94.

Muir, H. M., Neuberger, A. \& Perrone, J. C. (1 952 ). Biochem. $\mathscr{F} .52,87$.

Pauling, L. (1955). Harvey Lect. 49, 216.

Pett, L. B. (1952). Fed. Proc. 11, 453.

Pett, L. B. (1954). Fed. Proc. 13, 473.

Platt, B. S. (1955). Brit. med. F. i, I79.

Prankerd, T. A. J. (1955). Brit. F. Haematol. 1, 1 3 I.

Robineaux, R. (1952). Sang, 23, 730.

Robscheit-Robbins, F. S. \& Whipple, G. H. (1955). f. exp. Med. 102. 705.

Rogers, L. (1938). Brit. med. F. ii, 943 .

Smiley, R. K., Cartwright, G. E. \& Wintrobe, M. M. (1952). F. Amer, med. Ass. 149, 914. 
Tishkoff, G. H., Robscheit-Robbins, F. S. \& Whipple, G. H. (1953). Blood, 8, 459.

Tishkoff, G. H., Yuile, C. L., Robscheit-Robbins, F. S. \& Whipple, G. H., (1955). F. exp. Med. 102, 713.

Totterman, G. (1949). Acta med. scand. 134, Suppl. 230, p. 153.

Trowell, H. C., Davies, J. N. P. \& Dean, R. F. A. (1954a). Kwashiorkor, p. 65. London: Edward Arnold and Co. Ltd.

Trowell, H. C., Davies, J. N. P. \& Dean, R. F. A. (I954b). Kwashiorkor, p. Io2. London: Edward Arnold and Co. Ltd.

van de Kamer, J. H., Weijers, H. A. \& Dicke, W. K. (I953). Acta Paediat, Stockh., 42, 22.

Van Dyke, D. C., Contopoulos, A. N., Williams, B S.., Simpson, M. E., Lawrence, J. H. \& Evans, H. M. (r954). Acta haemat. Ix, 203.

Vaughan, J. (1948). Brit. med. F. i, 35.

von Bornsdorff, B. \& Gordin, R. (1952). Acta med. scand. 142, Suppl. 266, p. 283.

Waife, S. O., Wohl, M. G. \& Reinold, J. G. (1950). F. Lab. clin. Med. 36, 604.

Whipple, G. H. (1942). Amer. F. med. Sci. 203, 477.

Whitby, L. E. H. \& Britton, C. J. C. (1953). Disorders of the Blood. $7^{\text {th }}$ ed. London: J. and A. Churchill. Winfield, E. F. (1937). Chin. med. F. 51, 217.

Wintrobe, M. M. (1954). Bull. N. Y. Acad. Med. 30, 6.

Wintrobe, M. M. (1956). F. clin. Invest. 35, 89.

Woodruff, A. W. (1955). Brit. med. F. i, 1297.

Yuile, C. L. (1949). Science, II0, 44I.

Yuile, C. L., Lucas, F. V., Jones, C. K., Chapin, S. J. \& Whipple, G. H. (1953). Э. exp. Med. 98, 173.

\section{Anaemia associated with malnutrition in the tropics}

By A. W. Woodruff (Wellcome Professor of Clinical Tropical Medicine), London School of Hygiene and Tropical Medicine, University of London

During the past two decades workers in the tropics have become increasingly aware of the importance of anaemia among indigenous inhabitants and many believe that it is second only to malaria as a public-health problem. Certainly it is usual to find several cases of severe anaemia even in small hospitals throughout the tropics and not uncommonly half the patients in the medical wards and most of those in obstetric wards are moderately or severely anaemic. There is, of course, an enormous literature relating to the problem but most work has been concerned with a particular aspect of this group of diseases, and studies of the overall incidence of anaemia among different communities are comparatively uncommon. Napier (I940), however, drew attention to the great amount of morbidity and mortality associated with it in pregnancy in India. Dr M. K. Krishna Menon, Medical Superintendent of the Government Lying-in Hospital, Madras, in a personal communication states that at the hospital once every 6 weeks a pregnant woman dies as a direct consequence of anaemia and that one out of fifty of the patients has a haemoglobin level on admission of less than $5.6 \mathrm{~g} / 100 \mathrm{ml}$. Pandit (1948) reports maternal mortality rates in Madras of 16.6 per thousand live births, in Calcutta of 24.4 and in Bombay of 13.5 . Anaemia was responsible for $13.4 \%$ of the maternal deaths in Madras, $23.5 \%$ in Calcutta and $17.1 \%$ in Bombay; it was second only to puerperal sepsis in importance as a cause of maternal mortality. In the report of this investigation it is stated that 'anaemia may indirectly be responsible for a much larger proportion of maternal deaths than the above figures would indicate'. Foetal mortality among these cases 